\title{
TEACHING PROFICIENCY THROUGH READING AND STORYTELLING: A METHOD TO IMPROVE STUDENTS'SPEAKING ABILITY. (CLASS A OF ACCESS MICROSCHOLARSHIP PROGRAM BATCH 5 AMBON)
}

\author{
Nurul U. Namkatu \\ Universitas Pattimura \\ Ambon, Indonesia \\ nurulnamkatu@gmail.com
}

\begin{abstract}
Speaking is a very important skill that needs to be practiced in the classroom. However, students are commonly afraid to communicate in the classroom especially when it comes to oral communication. Based on the finding in the preliminary study the main reasons are the fears to get negative response towards their speaking ability and the lack of vocabulary. Therefore, to solve the problem, the researchers suggested the application of teaching Proficiency through Reading and Storytelling method. The method consists of three main steps namely Establish meaning, ask story and read and discuss the story. This study was conducted to determine the effectiveness of teaching proficiency through reading and storytelling method to improve students' speaking ability at class $\mathrm{A}$ of Access Microscholarship program batch 5 Ambon. Used Classroom action research as the method, the procedure of this research is consisted of four main steps; planning, implementing, observing, and reflecting through cycles. The instruments were Pre and Post speaking test. In the 2 nd cycle the result met the criteria of success. The criteria of success in this study is $75 \%$ of students can achieve the score 80 or exceed it. The data showed that in the second cycle, $80 \%$ of students have achieved the criteria of success. From this finding, it can be inferred that teaching proficiency through reading and storytelling method has proven to be able to improve students' Speaking ability.
\end{abstract}

Keywords: Speaking, Teaching Proficiency through Reading and storytelling method

\section{INTRODUCTION}

One of the main reasons that caused students to be hesitant and afraid to speak in English is because of the fear of getting negative response towards their speaking ability. It is in line with Piccolo (2010) as cited by Simanjuntak and Sihombing (2015) who said that the main causes of students' speaking problem are the fear in making error, receiving critics and being ashamed in front of the class. Another problem that increases students' fear to speak up in the classroom is the lack of vocabulary; while in this case, vocabulary plays an important part in speaking as it is fundamentally needed to form a sentence and to communicate with others. The problems above are discovered by the researcher as an English teacher in class A of Access Micro Scholarship program batch 5 Ambon. During the first semester of the English class, the students found it very difficult to speak in English because of the lack of vocabulary and the fear to get negative response towards their speaking ability. In line with the researcher, the students also stated that they find it difficult to speak because they are lack of vocabulary and afraid to get negative response towards their speaking ability. Therefore, the researcher applied Teaching Proficiency through Reading and Storytelling method or often called with the acronym TPRS method to improve students' speaking ability in Class A of Access Micro scholarship Program batch 5 Ambon. Reference [2] TPRS focuses on the acquirement of language by presenting the target language in an expressive, recognizable way through the use of stories that repeated rather than teaching grammatical rules or vocabulary lists. Through some interesting stories, students are not only having the chance to improve their vocabulary, but also repeat and most importantly speak and act them out. The creative ways in engaging students to participate in the classrooms activity through stories can definitely create a good outcome in term of students improvement in oral communication. The fun atmosphere will make students feel comfortable and forget about their fear to get negative responds towards their speaking ability, as everyone is having fun with the story that makes them stop thinking about judging or worrying about image. Reference [6] This argument is supported by Numpaque and Rojas who argued about the benefits of TPRS method that ...it encourages students to be very responsible for their learning as well as establish their self-assurance in using spoken language. 


\section{LITERATURE REVIEW}

\subsection{General Explanation of Speaking}

Speaking is a productive skill that enables people to communicate, share ideas and express their self through words in oral form. similarly, Reference [12] Torky stated that speaking is the students' skill to express opinion verbally, logically, assuredly and properly. As a skill that plays a very important role in communication, speaking should be the most urgent skill to be taught in the classroom. However, the importance of this skill is often be neglected in many classrooms. Until lately, Reference [3] even with its significance and delicateness, speaking is still an overlooked skill in many schools and universities because of the disapproving percentage of students and teacher and the traditional focus on grammar and culture. In some schools, speaking has been ignored mainly because of unfavorable teacher student ratios. It cannot be denied that speaking is not a favorite thing to do because the language learners are often afraid to speak the foreign language. The solution to overcome this problem is by providing the activities that make students enjoy the interaction without intimidating their pride that increases the feeling of insecurity in the classroom. In the same line with the researcher, Reference [7] Occhipinti argued that teachers need to set students to be contented in the classroom by not giving them the task that threaten their selfrespect and create rivalry between them.

\subsection{General Explanation of Vocabulary}

Reference [8] The meaning of vocabulary according to the Oxford dictionary is words that one's recognized and used. It means that vocabulary is not only about memorizing the words of target language, but also using the words in everyday conversation. In contradiction with the oxford dictionary, Webster as cited by Octaviany defined vocabulary as all the words that practiced by certain people and sometimes it also means all the words that acknowledge and agreed by a certain person without essentially being practiced by him (passive vocabulary). By looking to these statements the researcher believes that people need to use the words in context to prove that they understand the words. However, people often need time to really can put words into sentence although they understand the meaning. The large quantity of vocabulary in someone's head is also another reason why not all words that someone knows can be used as the speaker cannot just say random words that they remember, without adapting his/her responds to the content of conversation. Reference [5] Nation \& Waring mentioned that we are confident to say that evidently the second language learners need to know the 3,000 or so high rate words of the target language. Based on this statement, the importance of vocabulary needs to be emphasized to the students in order to raise their motivation in learning vocabulary as a key component to help them to speak. However, the role of the teacher is not to tell this standard as it can put many pressures on students. The main responsibility of teachers is only to give the students chances to know as many vocabularies as possible as well as guide them to use the vocabulary in context by providing activity that support this goal.

\subsection{The History and Definition of TPRS Method}

TPRS stood for Total Physical Responds Storytelling, now after developed by Blaine Ray, it stands for Teaching Proficiency through Reading and Storytelling, Reference [1] Marsh in Beal stated that unlike Asher, Ray does not focus on the use of signs or body movements to present the vocabulary, because it is emphasizing too much on commanding and inerting the passive linguistic ability. From that statement, the researcher could infer that Ray did not do massive changing on Total Physical Responds Storytelling. The main difference is only in the ways of introducing vocabulary that not only focus on imperative command through Total Physical responds but also can be through pictures, videos, or authentic material.

Reference [4] Muzammil defined TPRS as a language teaching method intended to improve actual fluency by way of learners and educator using the second/foreign language during the class by talking about fascinating and understandable stories. As TPRS method is a method that using story as a tool in the classroom to give the input of vocabulary and the stimulus for students to speak, choosing the interesting story is a must. However, an interesting story is not enough as the story also should fit the students' level. It must not too long or too short as well as containing the vocabularies that are easy to be comprehend by students.

\subsection{The Steps of TPRS method}

Reference [10] Ray and Seely stated 3 basic steps of TPRS method, namely: Establish meaning, ask story and read and discuss the story.

$>\quad$ The first step is to establish the meaning. It can be through various activities such as write the vocabulary in form of words or phrases in the white board, personalized the meaning through gesture, picture etc.

$>\quad$ The second step is to ask story. The teacher will stimulate students to "Tell" or build story by personalized some questions related to their personal experience, feeling and opinion towards something (still using the target vocabulary to ask and expect answer) the story line is still under the control of the teacher, but the students can add names of the character, gender etc through the question that the teacher give. Reference [10] Ray and Seely stated that the teachers have options to ask yes or no, either/or or WHquestions such as who, what, when, where, why, etc. However, the beginner teachers of TPRS are suggested to challenge the students by not always give the binary type questions (yes/no, either/or). This stage can be recognized as the "First tell" where the teacher tell a story while still 
expecting the contribution from students to complete the story. When the stories completed, then the teacher should ask students to read the written version of the story with physical movement or pictures. Reference [10] Ray and Seely stated that teacher needs to make sure that all the questions and phrases that are going to be used to form the story are written visibly in the board along with their translation. This is to avoid the misunderstanding in translating the story. As the teacher completes the "First tell" and the reading stages, the next activity would be the second "Tell". Apart from the mini story that created together, the teacher has a complete story that similar to the "class story" then the teacher will tell and retell that several times (with pictures or physical movement). In this stage, printed story is also needed to be handed to the students, in order to let them read and listen to the story at the same time. After that, the teacher then switching from "Tell" to ask question about the story with students, it can be yes/no questions, W/H questions or other form of questions.

$>\quad$ The last step is to read and discusses the story (including a brief translation and questioning sessions). This is the step where the teacher and students will reinforce the content by reading the story, and then the teacher will retell the story in a new perspective, and ask students to retell the story in a new perspective as well. For example: if the story using "She" to describe the characters, the teacher and students will use "I" or "We".

\subsection{The Function of TPRS Method in Teaching Speaking}

Reference [5] Students are often giggling over humor. It actually can stimulate a long-term reminiscence and encourage a good attitude to the target language. In the TPRS story telling, teacher has the authority to choose the story or situations that will be acted out by his/her students. The story can be funny, enjoyable, or contain a lot of moral value, as long as the story is relevant to the level of students. The humor can create a positive attitude towards the target language which can catch students' attention and keep them away from the boring situation. The repetition of stories and words in TPRS procedure are also the main point that promotes a better memory of the words given to them. TPRS also improves fluency with correctness. Pupils obtain language in an entertaining way, which allows them to use it Through the 3 steps of TPRS namely "Establishing meaning, tell/ ask story and read and discuss "students will have chance to speak in the retelling stage as well as the discussion stage through some personalized questions that given by the teacher. Reference [10] The positive impacts of TPRS that already stated in the previous explanation are also firmly supported by Ray and Seely, when they cited Seely and Romji that TPRS is an effective method to improve students' capacity to speak fluently, persuade students to use the power of their mind and creativity, encourage students to take the main role in their own learning and establish students' self-reliance in doing the oral activity.

\subsection{TPRS Classroom Management and How to Maintain} Students' High Interest

As happens all the time, students are usually started the semester or even a class with high excitement. However, as time pass, the excitement and energy is slowly disappeared. To overcome this problem, the classroom teacher needs to know some techniques that can be used to preserve students' high interest. For that reason, the researcher stated three of Reference [10] seven techniques that proposed by Ray and Seely namely:

1. Preserve students' interest through comedy. Comedy that delivered by exaggerating, personalizing as well as showing weird expression or mimics to the students can maintain high interest in the classroom.

2. Preserve students' interest by showing enthusiasm and excitement towards the story. Students will feel uninterested if the teacher does not put enthusiasm in teaching especially in reading or delivering the story. On the other hand, if the teachers' body language, appearance and voice show eagerness, the students will surely feel the same way.

3. Preserve students' interest by personalize the story. The made up story about students' date with their favorite singer or other stories that related to their daily life will be very helpful to maintain high interest in the classroom.

Those three techniques are very helpful to overcome some problems that often happen in the classroom namely the boring content of material, teachers' negative attitude and students' less involvement in the classroom. Therefore, to apply those techniques means to preserve students' high interest on the lesson.

\section{RESEARCH METHODOLOGY}

Classroom action research (CAR) is the methodology that the researcher applied in this research. In this case, the researcher as the English teacher in Access Micro Scholarship Program did a research to find out the effect of TPRS method on students' speaking improvement in a specific classroom that consist of 20 students namely class A. The procedure of this research consists of: Planning: In this stage, the researcher prepared the research schedule, lesson plan, instruments and all things that related with the research process. Acting: In this stage, the researcher applied the TPRS method to improve students' speaking ability. Evaluating/ Developing: In this stage, the researcher evaluated the students' speaking improvement through the data collected. 
Reflecting: In this stage, the researcher analyzed the result whether it is success or fail.

The research was conducted at the Access Micro Scholarship Program Batch 5 Ambon, specifically in class A. The students in this class are the first graders of senior high school, who are selected to follow free English course (Access class) twice in a week for two years. The class consists of 20 students. The data was collected by pre and post test and was analyzed by using speaking assessment rubric. The indicator of success is $75 \%$ of the students got the score at least $80-$ 100 points.

\section{RESULT AND DISCUSSION}

\subsection{First Cycle}

The result of students' speaking ability in the pre test shows that only $15 \%$ (3 students) that are in the good level, $60 \%$ of students (12 students) are in the fair level and $25 \%$ of students (5 students) are in the weak level. There are 3 students in the good level, however those three students are still cannot hit the score 80 . In the fair level, the scores are around 65 until 69. Furthermore, in the weak level, the scores are around 55 until 62.

Thus, the researcher could infer that the students are still lack in speaking ability. The researcher then decided to implement the TPRS method, to improve students' speaking ability. The criteria of success that set by the researcher is $75 \%$ of students can get the score 80 until 100. In the first cycle, the result of their post test scores shows that $50 \%$ (10 students) are in the good level, $45 \%$ (9 students) are in the fair level and only $5 \%$ (1 student) are in the weak level. However, most of the students have not achieved the criteria of success yet. Only $20 \%$ (4 students) can achieve the criteria of success (80-100), while $80 \%$ others are still could not hit or exceed the criteria of success. To be detail, here the explanations of Students speaking performances that have not meet the indicator of success, from four categories that rated in the speaking rubrics:

1. Vocabulary: In the Vocabulary category, there are 11 students that still in the fair level which means that they made noticeable vocabulary errors that occasionally confuse the meaning in their speaking performances. There is also one student that still in the weak level which means that she made many vocabulary errors and the meaning of her words are often unclear. The Vocabulary errors that the students often make are in the use of adjective, they often confuse with the meaning of one adjective and another ( example: expansive and cheap), and they also often forget the meaning of some nouns that they want to use in a sentence but quickly recover and remember or correct the mistakes by their selves.
2. Fluency: In the Fluency category, there are 7 students that still in the fair level which means that they made noticeable gaps that catch the listener attention and usually followed by recovery in their speaking performances. Furthermore, there are 9 students that still in the weak level which means that they made several period of silence and several gaps that disrupt the flow of information in their speaking performances. Students made several gaps and silence in the fluency category, the silence and gaps are often due their nervousness.

3. Pronounciation: In the Pronounciation category, there are 6 students that still in the fair level which means that they made noticeable errors that confuse meaning in their speaking performances. Furthermore, there are 2 students that still in the weak level which means that the language is mark with pronounciation errors and meaning is often unclear. Students often forget how to pronounce some words although they already learnt about it, due to nervousness or lack of individual exercise.

4. Grammar: In the Grammar category, there are 5 students that still in the fair level which means that they made noticeable errors of grammar that occasionally confuse the meaning $\mathrm{n}$ their speaking performances. Furthermore, there are 6 students that still in the weak level which means that the grammar errors made an unclear meaning of the language. The Grammar errors that the students often make are in the use of possessive pronoun. For example: they don't say her friend but she friend; they don't say your house but you, she, he house. They also have problems in using article and present perfect tense related to the materials about adventures.

Based on the previous explanation, the researcher can infer that students speaking ability have not improved significantly and decided to do the second cycle. To overcome the problems, the researcher motivated the students to be more confident, allocated more time to the grammar explanation about the material through game and made many repetitions in teaching vocabulary by including videos about comparison of celebrity that played repeatedly to catch their attention and train their listening skill while repeating the words.

\subsection{Second Cycle}

After implementing TPRS method in the second cycle, the result of students' speaking test increased significantly: $35 \%$ (7 students) are in the very good level, 60\% (12 students) are in the good level, and only $5 \%$ (1 student) is in the fair level while none is in the weak and unacceptable level. The results also shown that $80 \%$ (16 students) have achieved the criteria of success namely 80- 100 points, while the other $20 \%$ (4 students) have not achieved the criteria of success yet. However, they are still in the good level. Students can be said to have good speaking performances when they can speak in front of people at least without many hesitations and pauses with mostly correct grammar and vocabulary. The results of this research found that the students have met the indicator of success through their performances in the test after implementing the TPRS method in the second cycle. 


\section{CONCLUSION AND SUGGESTION}

\subsection{Conclusion}

After implementing TPRS method in two cycles, the researcher comes up with a conclusion that:

1. The result of the research indicates that students' speaking ability is improved after being taught by TPRS method. It is proved by their speaking test scores.

\subsection{Suggestion}

For the English teachers, the researcher suggests to use the TPRS method to teach speaking in the English classroom, the findings of students speaking score is very positive. However, the researcher also suggests to not using too long difficult story in TPRS classroom. The level of difficulty of the story should always suit the students' English level. In TPRS classroom, the possibility of the class to be noisy is very high. Thus, the teacher needs to establish a sign to gather students' attention before practicing this method. For further researcher, the researcher recommends to try to implement the TPRS method in the elementary or junior high school students. The level of difficulty of the vocabularies and story that will be taught can be adjusted with the elementary and junior high school level. Besides, children love stories. Thus, the method must be succeeding in improving their speaking ability.

\section{References}

[1] Beal David K (2011), The Correlates of Storytelling from the Teaching Proficiency through Reading and Storytelling (Tprs) Method of foreign language instruction on anxiety, Continued Enrollment and Academic Success in Middle and. Thesis (online). http://kuscholarworks.ku.edu/bitstream/handle/1808/7915 /beal_ku_0099D_11358_DATA-1.pdf? Retrieved February $23^{\text {rd }}, 2016$

[2] Brune Michael K (2004), Total Physical Response Storytelling an analysis and application. Thesis (online). https://scholarsbank.uoregon.edu/xmlui/bitstream/handle/.
../TPRSthesisFINISHED.pdf, Retrieved September $23^{\text {rd }}$, 2016

[3] Egan B Kathleen (1999), Speaking: A Critical Skill and a Challenge.

https://journals.equinoxpub.com/index.php/CALICO/artic le/download/23354/19359, Retrieved February $23^{\text {14 }}$, 2016. Calico Journal (online).' 16 (3) 277-293

[4] Muzammil Lasim \& Andi (2015), Improving Speaking Skill by Using Teaching Proficiency through Reading and Storytelling (TPRS). Thesis (Online). http://repository.unikama.ac.id/385/1/Full\%20Paper\%20T PRS\%20presented\%20at\%20NELTAL\%202015.pdf Retrieved December $21^{\text {st }}, 2016$

[5] Nation Paul \& Waring Robert (1997) Vocabulary Size, Text Coverage and World List. Journal (Online). ISSN 0121-053X, p. 151-162 (1997), http://www.robwaring.org/papers/CUP/cup.html Retrieved $25^{\text {tI }}$ June 2016

[6] Numpaque B.R Nidia, Rojas G.A. Miguel (2010), TPRS A key to speak fluently in English. (Online.) https://dialnet.unirioja.es/descarga/articulo/3673486.pdf , Retrieved March 23 ${ }^{\text {th }}, 2016$.

[7] Occhipinti Alessia (2009) Foreign Language Anxiety inClass Speaking Activities - Two Learning Contexts in Comparison. Thesis (Online). https://www.duo.uio.no/bitstream/handle/10852/../Daxsta mparexoggixultima.pdf , Retrieved February 23 $3^{\text {id }}, 2016$

[8] Octaviany Yenny (2007), The Application Of Total Physical Response In Teaching English Vocabulary To The Fourth Graders Of Sd Negeri 04 Krajankulon Kaliwungu Kenda .Thesis (Online). http://lib.unnes.ac.id/1405/1/2281.pdf , Retrieved August $08^{\mathrm{n}}, 2016$

[9] Oxford learners pocket dictionary (2008). Fourth Edition. United States of America: Oxford University Press

[10] Ray Blaine \& Seely Contee (2015): Fluency through Reading and Storytelling. Seventh Edition. United States of America: Command Performance language institute

[11] Simanjuntak rofina yeny, Sihombing Lince on their study (2015) "The effect of using total physical response story telling on students". Thesis (Online).

http://jurnal.unimed.ac.id/2012/index.php/eltu/article/vie W/2106, Retrieved February $23^{\text {th }}, 2016$

[12] Torky F.E.A Shiamaa (2006), The Effectiveness of a Task- Based Instruction program in developing the English Language Speaking Skills of Secondary Stage Students.Thesis (Online) https://eric.ed.gov/?id=ED523922 , Retrieved December $20^{\text {th }}$, 2015 